\begin{tabular}{ccc} 
FOLI A & $\begin{array}{c}\text { ENTOMOLOGICA } \\
\text { ROVARTANI HÖZLEMAR A R I A }\end{array}$ \\
Volume 80 & 2019 & pp. $287-291$ \\
\hline
\end{tabular}

\title{
First record of Thysanoplusia orichalcea in Hungary (Lepidoptera: Noctuidae: Plusiinae)
}

\author{
Diána BALOGH ${ }^{1} \&$ Balázs Tó TH ${ }^{2 *}$ \\ ${ }^{1}$ H-7192 Szakály, Fö út 34, Hungary.E-mail:baloghdia1985@gmail.com \\ ${ }^{2}$ Hungarian Natural History Museum, Department of Zoology, \\ H-1088, Budapest, Baross utca 13, Hungary.E-mail:toth.balazs@nhmus.hu
}

\begin{abstract}
One Thysanoplusia orichalcea female specimen was collected in Szakály, Tolna county, for the first time in Hungary. Occurrence of the species in Hungary is not unexpected, and it could repeatedly migrate to Central Europe in the next years due to climate change. With 3 figures.
\end{abstract}

Key words - citizen science, climate change, migrant, new record, Oriental region, pest, Thysanoplusia intermixta

\section{INTRODUCTION}

Thysanoplusia orichalcea (Fabricius, 1775) is originally an Oriental species, but spreads in Asia, Europe, Africa, Australia and New Zealand, i.e. all Old World continents (STRINGER et al. 2008). The moth is a regular migrant along the Mediterranean coasts of Europe (GOATER et al. 2003); all other European records are based on occasional migrant specimens. This species can be distinguished from all other European taxa of Plusiinae by the distinctive golden pattern of the forewing: majority of the terminal field is golden, there is a patch protruding to the medial field below the cell, close to the orbicular stigma, therefore the whole golden area is somewhat toe-shaped. The Oriental tropics and the Eastern Palaearctic region are inhabited by several related taxa of which Th. intermixta (Warren, 1913) is the most similar to Th. orichalcea. The two species can be separated by the less distinct subterminal line, the more pointed basal end of the golden field and the darker hindwing of $T h$. orichalcea, compared to the other species (Holloway 1985). Th. orichalcea is polyphagous, and regarded as a pest in tropical countries, feeding e.g. on Brassica spp., Helianthus annuus L., Medicago sativa L. and Glycine max (L.) Merr. (RoBInson et al. 2010).

In this paper we present the first Hungarian record of $T h$. orichalcea.

${ }^{*}$ Corresponding author. 


\section{MATERIAL AND METHODS}

One female Thysanoplusia orichalcea attended a tungsten lamp on the terrace of a house in Szakály, Tolna county, on 18 October 2019, around 19:45. The moth was restless, flew around the bulb, then shortly disappeared; a few seconds later it was found sitting in a shady corner underside of the roof of the terrace. The moth was captured alive; a photograph was taken on it (Fig. 1) with a Fuji FinePix S8000fd camera and was preliminarily identified by the first author.

The image of the specimen was uploaded to a Facebook group where it was detected by Balázs Károlyi, owner of the website www.izeltlabuak.hu. He sent the image to the second author who confirmed the preliminary identification and asked the first author to donate the specimen for the Hungarian Natural History Museum (HNHM, Budapest).

The specimen was put in a freezer, and subsequently set in the Lepidoptera Collection of the HNHM, and labelled as follows: H - Tolna megye, Szakály, Fő út 34., fényre (W-izzó), 2019.X.18., leg. Balogh Diána (Fig. 2). Specimens of HNHM were photographed with an Olympus Camedia C 7070 camera.

\section{RESULTS AND DISCUSSION}

Identification of the specimen as Thysanoplusia orichalcea was confirmed by the presence of the indistinct subterminal line and the basally pointed golden field of the forewing as well as by the dark ground colour of hindwing. These traits are shared by all $T h$. orichalcea specimens housed in the HNHM Lepidoptera world collection (329 specimens). The HNHM has not kept any Th. orichalcea specimen from the Carpathian Basin, but contains specimens of European origin as the next entry reports.

It is noteworthy that works in the first half of the 19th century (e.g. TREITSCHKe 1826, 1835) involved the taxon "Plusia orichalcea", however, they actuallyapplied thisnametowhat weknow today asDiachrysiachryson (Esper, 1789). The species Th. orichalcea appears in these works as "Plusia aurifera".

We located one original Ochsenheimer specimen of Th. orichalcea (Fig. 3). In the unpublished Ochsenheimer catalogue** two specimens are indicated as "Noctua Aurifera".

Th. orichalcea is not listed in the latest Hungarian checklist (PASTORÁLIS et al. 2016). ABAFI-AIgNER (1907) also did not include this species in his work, which means that no specimen was observed, even from the Mediterranean coastal habitats of Croatia in the former Hungarian Kingdom.

\footnotetext{
**Anonymus 1824: Néhai Ochsenheimer Ferdinand nyugalmazott cs. kir. udvari szinész, bölcsészet tanára és több tudós társasági tag pillangó-gyüjteményének lajstroma. [Checklist of the Lepidoptera collection of the late Ferdinand Ochsenheimer, retired actor of the Imperial-Royal Court, professor of phylosophy and member of several scientific societies.] Five-page manuscript in the HNHM Lepidoptera Collection.
} 
The species is a pest in several subtropical or tropical countries. Overwintering of Th. orichalcea in Hungary is unlikely in the near future due to heavy winter frost, therefore, even if it may cause damage in Hungary in the next years, this would remain negligible.

The weather of the year 2019 was apparently comfortable for migrant Plusiinae species. Especially Chrysodeixis chalcites (Esper, 1789) became unusually frequent, with most occurrences along the Danube river, from as south as the Gemenc forest, Tolna county (Tamás Korompai et al., unpublished data) to as north as Koroncó, Győr-Moson-Sopron county (József Káldi, pers. comm., see KÁ ROLYI 2016). Most Ch. chalcites individuals visited light but some of them were attracted by baits of red wine and sugar. Trichoplusia ni (Hübner, 1803) also occurred: one individual was taken near Balatonakali, Veszprém county (coll. HNHM). Not only migrant Plusiinae species were conspicuously present in 2019, but Vanessa cardui (Linnaeus, 1758) also developed unusually high individual number. During a night at early July three individuals were collected even by a portable light trap in Börzsöny Mountains, Pest county (Gergely Katona et al., unpublished).

The Th. orichalcea individual we report in this paper was observed in a dry, sunny and warm period, with highest daily temperatures often exceeding $25^{\circ} \mathrm{C}$, lasted for two weeks. Since this species was previously recorded as north in Europe as the Netherlands and even in England (GoATER et al. 2003), the Hungarian occurrence cannot be regarded as unexpected. Moreover, the probable increase of the frequency of such long dry and warm spells due to climate change will likely lead to increase the occurrence of $T h$. orichalcea and other subtropical migrant species.

The first Hungarian record of Th. orichalcea is also an example showing the usefulness of citizen science.

Acknowledgements - We are grateful to Balázs Károlyi (Budapest) for facilitating communication between us. We are indebted to Zsolt Bálint (HNHM) who checked and significantly improved the manuscript. 

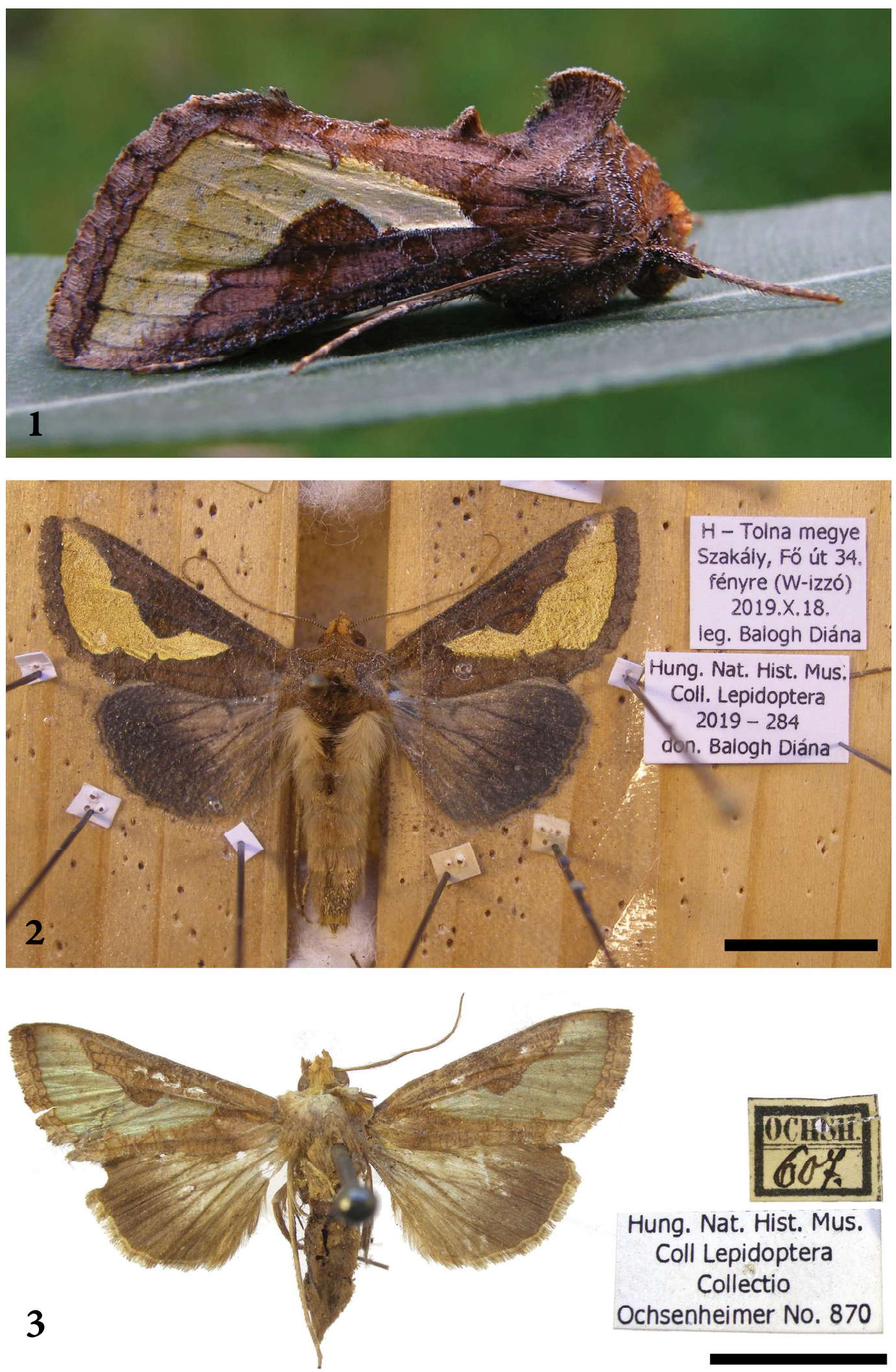

Hung. Nat. Hist. Mus.

Coll Lepidoptera

Collectio

Ochsenheimer No. 870

Figs 1-3. Thysanoplusia orichalcea specimens: $1=$ alive individual in Szakály, Tolna county (photo by Diána Balogh), 2 = the specimen and its labels on a setting board in the HNHM, $3=$ the specimen from the Ochsenheimer collection. Scale bars $=10 \mathrm{~mm}$ (photos by Balázs Tóth) 


\section{REFERENCES}

A BAFI-Aigner L. 1907: Magyarország lepkéi, tekintettel Európa többi országának lepke-faunájára. A Berge-féle lepkekönyv képeivel. [Lepidoptera of Hungary, with regards to the lepidopteran fauna of the remaining countries in Europe. With images from Berge's book on Lepidoptera.] Athenaeum Irodalmi és Nyomdai Részvénytársulat, Budapest, XXXII+123 pp, 51 pls.

Goater B., Ronkay L. \& Fibiger M. 2003: Noctuidae Europaeae. Volume 10. Catocalinae \& Plusiinae. - Entomological Press, Sorø, $452 \mathrm{pp}$.

Holloway J.D. 1985: The moths of Borneo, part 14: family Noctuidae, subfamilies Euteliinae, Stictopterinae, Plusiinae, Pantheinae. - Malayan Nature Journal 38: 157-317.

KÁROLYi B. 2016: Ízeltlábúak.hu - segitünk egymásnak megismerni Magyarország izeltlábú élövilágát. [Arthropods.hu - we help each other to explore the arthropod fauna of Hungary.] http://www.izeltlabuak.hu. [Accessed 20 October 2019.]

Pastorális G., Buschmann F. \& Ronkay L. 2016: Magyarország lepkéinek névjegyzéke Checklist of the Hungarian Lepidoptera. - e-Acta Naturalia Pannonica 12: 1-258. http://epa.oszk.hu/01900/01957/00017/pdf/ [Accessed 20 October 2019.]

Robinson G. S., Ackery P. R., Kitching I. J., Beccaloni G. W. \& Hernández L. M. 2010: HOSTS - A database of the world's lepidopteran hostplants. Natural History Museum, London. - https://www.nhm.ac.uk/our-science/data/hostplants/ [Accessed 20 October 2019.]

Stringer L. D., El-Sayed A. M., Cole L. M., Manning L. A. M. \& Suckling D. M. 2008 : Floral attractants for the female soybean looper, Thysanoplusia orichalcea (Lepidoptera: Noctuidae). - Pest Management Science 64(12): 1218-1221. https://doi.org/10.1002/ps.1621

Treitsch Ke G. F. 1826: Die Schmetterlinge von Europa. Fünfter Band. Dritte Abtheilung. [Moths and butterflies of Europe. Fifth volume. Third part.]. - Gerhard Fleischer, Leipzig, 419 pp. https://doi.org/10.5962/bhl.title.50612

Treitschke G. F. 1835: Die Schmetterlinge von Europa. Zehnter Band. Zweite Abtheilung der Supplemente. [Moths and butterflies of Europe. Tenth volume. Second part of supplement.]. Ernst Fleischer, Leipzig, 340 pp. https://doi.org/10.5962/bhl.title.50612 